\title{
The contract-of-employment test renewed A Scandinavian approach to platform work
}

\author{
Marianne Jenum Hotvedt \\ Associate professor, Labour Law Research Group \\ Department of Private Law, University of Oslo
}

Recibido: 6.2 .2018

Aceptado: 3.3.2018

DOI: https://doi.org/10.20318/sllerj.2018.4436

\begin{abstract}
Platform work blurs the scope of labour law and challenges the contract-of-employment test, threatening effective labour law protection. This article analyses this challenge from a Scandinavian perspective, where the contract-of-employment tests share common features and where a core common challenge is the ambiguous nature of worker freedom: When does the freedom to choose tasks and hours indicate autonomy and when does it indicate (extreme) precarity?

As the criteria guiding the test leave this issue unresolved, the article argues that a renewal is required and suggests how it can be achieved. The purposive approach rooted in Scandinavian jurisprudence allows for both an individual and a market perspective, and provides a basis for a careful renewal of the test. The article concludes by suggesting new -or updated-criteria guiding the contractof-employment test when dealing with platform work.
\end{abstract}

Keywords: platform work, crowdwork, contract of employment, concept of employee.

\section{Introduction}

This article builds on an understanding of platform work as work-intensive services for pay, generated through a digital platform acting as an intermediary that matches the supply and demand for such services using information technology. ${ }^{1}$ This includes both services provided digitally (online work) - such as translations or PowerPoint presentations - and services provided in a physical environment - such as transport or cleaning -, but excludes internal crowdwork. ${ }^{2}$

Platform work is performed within a triangular (or multi-angular) structure, involving the person performing work (the worker), the end user (the customer; private or professional) and the company or companies providing the digital intermediary service (the platform). ${ }^{3}$ A significant novel feature of platform work is the technology that matches supply and demand by connecting a large pool of workers to a large (indefinite) number of customers at high speed and with minimum transaction costs. This arrangement blurs the lines between a market and a hierarchy, and challenges the traditionally dominant form of hierarchy - the firm - as the effective organizing mechanism. ${ }^{4}$ It allows the platform to profit from organizing labour on a large scale, while apparently limiting legal responsibilities and the need for investments.

\footnotetext{
${ }^{1}$ This builds on the three central aspects of the 'sharing' or intermediary economy identified by Roverud et al. (2017): A digital platform acts as an intermediary, contributing towards matching complementary actors (suppliers and customers) who exchange different kinds of services. As indicated, the present work, however, focuses on work-intensive services for pay.

${ }^{2}$ De Stefano (2016) distinguishes between crowdwork (work executed through online platforms) and 'work-on-demand via app' (traditional working activities offered and assigned through mobile apps). Prassl and Risak (2016) distinguish between external and internal crowdwork.

${ }^{3}$ The Commission defines the term 'collaborative economy' with reference to the triangular structure, see COM(2016) 356 final.

${ }^{4}$ Platforms can thus be seen as a new firm-market hybrid, see Sundararajan (2016), 77.
} 
Thus, platform work challenges the legal framework, not just in labour law, but also in other areas such as tax and social security law, market law, competition law and consumer law. The contractof-employment test plays a vital role when facing this challenge. The test classifies work relations with specific characteristics and attaches a distinctive set of legal consequences - a broad range of employer duties in different fields of law - to such relations. Applying the contract-of-employment test to platform work is therefore also a test of the legal framework's ability to adapt to a novel work arrangement. As will be elaborated, as the test currently stands, when applied to platform work, a grey area threatens effective labour law protection. A pressing question therefore concerns how the contract-of-employment test should be applied to platform work.

The article analyses this question from a Scandinavian perspective. The aim is to contribute to a clearer distinction between platform employees and platform contractors. The article argues for a careful renewal within the current jurisprudential tradition and suggest renewed - or updated - guiding criteria.

The chosen focus for analysis is the platform-worker relation. This relation is a novel feature of platform work and it seems more representative of the fundamental conflict between capital and labour than the worker-customer relation does. As further analysis will show, the focus on this relation will, however, allow for a comprehensive approach to the complex structure of platform work.

The article starts by reflecting on the significance of the contract-of-employment test and by relating the challenges of classifying platform work to known grey-area problems, and concludes with a need to renew the test (section 2). Then, the Scandinavian approach is introduced (section 3). The common features of the Scandinavian contract-of-employment tests are presented and discussed in comparison with British law to highlight the specific challenges in the Scandinavian context. This section argues that from a Scandinavian perspective, the core common challenge of platform work is neither formal arrangements nor the triangular structure, but the ambiguous worker freedom this structure gives rise to. As the traditional criteria provide little guidance on this challenge, this section concludes that it is a requirement to renew the existing criteria.

The question of how to renew the criteria is discussed in the third part of the article (section 4). Building on the purposive element in the Scandinavian tests and the comprehensive approach to other triangular structures, the article argues for a broad purposive approach, including both the traditional perspective of the individual's need for protection and a market perspective assessing the market role of platforms, while considering Scandinavian labour-market values.

In conclusion, the article suggests renewed criteria guiding the contract-of-employment test when dealing with platform work (section 5).

\section{The challenges of classifying platform work}

\subsection{A necessary test}

The contract of employment is a fundamental feature in labour law across jurisdictions. ${ }^{5}$ Statutory labour standards are predominantly framed as duties resting on the stronger party of the employment contract (the 'employer') to protect the interests of the weaker party (usually named the 'employee'). The contract of employment therefore serves as a gateway to labour law protection. This reflects the classic rationale of labour law; legal protection aimed at redressing the inherent power asymmetries in the employment contract. ${ }^{6}$ Consequently, the legal test classifying this contract, making the distinction between employees and independent contractors, plays a key role in determining the scope of protection. It also forms a vital connection between individual and collective labour law. The individual contract of employment is a legal basis for collective autonomy, as the fundamental function of collective labour law is to align the power asymmetries in the individual relation. ${ }^{7}$

\footnotetext{
${ }^{5}$ For a comparative overview, see Casale (2011).

${ }^{6}$ See Veneziani (1986) for a historic account, Perulli (2011) for a European perspective and Berg (1930), 5-7 for a Scandinavian perspective.

${ }^{7}$ For a Nordic perspective, see Evju (2010), with references to the same basic approach in German law.
} 
Identifying such a contract is, however, not necessarily crucial to all aspects of labour law protection. Protective rules may apply to other work relations than the contract of employment, reflecting an expanded and nuanced protective rationale. Depending on the jurisdiction, certain aspects of statutory protection may apply to work relations without a contractual basis and to other types of contracts or work relations. ${ }^{8}$ Even genuinely independent contractors may be covered by specific protective rules. ${ }^{9}$ Although the entity responsible for providing such protection may be named the 'employer', the duties conferred to the 'employer' are not inextricably related to a contract of employment. Some employer duties may apply to other work relations and serve to align other positions of power. Consequently, the assumption of a conceptual 'link' between the contract of employment and the concept of the employer is debatable. ${ }^{10}$

That being said, the contract of employment is still the cornerstone of, and the main gateway to, labour law protection, as it generally triggers a full range of statutory employer duties providing protection for the individual. Furthermore, the contract of employment has important functions in other fields of law. In tax and social security law, insurance and tort law, a contract of employment produces specific legal consequences for both parties in relation to the government and to other private actors. ${ }^{11}$ Furthermore, the contract-of-employment test shares important features with key concepts and distinctions in other fields of law such as the concept of an undertaking in competition law and the classification of services in market law. ${ }^{12}$

This brief account illustrates the key role of the contract-of-employment test in the current legal framework: While the contract of employment triggers a distinctive legal regime protecting the weaker party, contracts for services operate under the fundamentally different rules of civil and commercial law, basically leaving independent contractors to protect themselves through individually bargained contractual provisions. The contract-of-employment test is therefore in some sense necessary: The distinction between employees and independent contractors is deeply entrenched in the existing legal framework both on the national and EU level, and both from an individual and a collective perspective. ${ }^{13}$ From a practical perspective, this is not likely to change. Although the foundation and conceptual framework of labour law is under continuous debate, it is hard to imagine the contract of employment losing significance anytime soon. ${ }^{14}$

One perhaps obvious point of departure is that platform work cannot be classified as such. Platform work is heterogeneous. Platform models, terms, conditions and types of work vary, and platform workers do not share the same characteristics. ${ }^{15}$ It is therefore necessary to draw a distinction within platform work, separating platform employees from platform contractors. This is where the contract-ofemployment test is challenged.

\subsection{The grey area}

The challenge of classifying platform work is recognised by the European Commission and national governments. ${ }^{16}$ Ideally, the contract-of-employment test should draw the distinction in a clear

\footnotetext{
${ }^{8}$ Such nuances in Norwegian labour law are discussed in Hotvedt (2016a).

${ }^{9}$ In particular, health and safety provisions and protection against discrimination are extended to cover independent contractors, see further on Swedish law in Selberg (2017) and on Norwegian law in Hotvedt (2016a).

${ }^{10}$ See recent discussions in Prassl (2015), Hotvedt (2016a) and Selberg (2017).

${ }^{11}$ Some examples from Scandinavian law are presented in section 3.

${ }^{12}$ On the concept of an undertaking in competition law in relation to labour law, see i.a. Hjelmeng (2016). Classification of services in market law is visited in section 4.2 .

${ }^{13}$ The distinction is also important for the scope of various ILO instruments. However, the concept of worker in some of these instruments is arguably wider and may include independent contractors, see Creighton and McCrystal (2016).

${ }^{14}$ Labour law's personal scope - the concept of the employee and/or worker - has traditionally been in focus, see i.a. the seminal contributions of Supiot (2001) and Freedland and Kountouris (2011). An approach more examined in recent years focuses on the responsible party (or parties) - the concept of the employer -, see i.a. Prassl (2015), Hotvedt (2016a) and Selberg (2017).

${ }^{15}$ See i.a. De Stefano (2016), 473-480, Prassl and Risak (2016), 621 and, from a Nordic perspective, Dølvik and Jesnes (2017), 22-26.

${ }^{16}$ The Commission address the challenge in i.a. $\operatorname{COM}(2016) 356$ final and $\operatorname{COM}(2017) 250$ final 'Establishing a European pillar of social rights'. Scandinavian governments have initiated several studies and commissions. In Norway, see in particular NOU 2017:4 (the report of the Sharing Economy Commission) and Fafo-notat 2017:41 (an empirical study of actors and work in the sharing economy). In Sweden, see in particular SOU 2017:24 (on challenges for the working environment), SOU
} 
and operational manner, providing fairness and predictability for everyone involved. When faced with platform work, the test fails this challenge and a grey area remains.

Grey-area challenges are nothing new. One known problem concerns 'sham' or disguised employment contracts; subordinate, dependent work with the formal appearance of autonomous work. In principle, this is an enforcement issue. Yet it is related to the legal nature of the contract-of-employment test, as vagueness and a lack of clear guidance can facilitate and perhaps encourage sham arrangements.

Second, work relations with both subordinate and autonomous features do not fit the binary 'allor-nothing' logic. This is both a scope issue and an issue of what the protected-status entails. Discussions on intermediary categories and more nuanced protection for employees are efforts to respond to this challenge. One example is the concept of the worker in British law, connecting specific aspects of dependency with certain rights such as a minimum wage and working-time protection, but not with the full range of rights conferred to employees. ${ }^{17}$

Employer-side fragmentation is a third issue. The contract-of-employment test, with its contractual basis, is challenged if several entities are involved. Who - of several possible entities - is the responsible employer? One type of fragmentation concerns triangular contractual structures of work such as agency work. Complex corporate structures are another manifestation. Fragmentation can potentially represent a scope issue depending on whether the contract-of-employment test allows for a comprehensive approach to complex structures. However, even if labour law protection is applicable, fragmentation challenges the allocation of employer duties.

Platform work combines these grey-area challenges with a potentially amplifying effect.

The sham problem is highly relevant. Operating outside the scope of labour law is an essential part of the business model. Although heterogeneous, platforms generally base their activities on the assumption that labour law protection does not apply. ${ }^{18}$ Obviously, such assumptions should not be accepted as such. The judgment against Uber in the UK illustrates how platform work can be dependent work in disguise. ${ }^{19}$ This may illustrate the need to question platform models more broadly.

Furthermore, platform work typically has both autonomous and subordinated features. The workers are usually free, at least formally, to decide on the amount of work they do, what tasks to perform, and to choose the time and place for their work. The platform is often not directly involved during the work performance, the workers typically provide the necessary tools and equipment themselves and may also be allowed to hire employees or use subcontractors. Remuneration is apparently provided by the customer. The traditional dependent-labour characteristics (continuous personal work under supervision and control in exchange for remuneration) are therefore apparently lacking.

Yet the freedom of platform workers is ambiguous. The absence of the worker's obligation to accept work is reflected by the absence of the platform's obligation to provide work and pay, and the workers' profit possibilities can be limited. Economic dependency can therefore be the harsh flip side of freedom. For workers operating alone, such dependency is, in reality, of a personal nature. Technology provides new means to control workers both as individuals and as a crowd. Work performance can be monitored online and control can be 'outsourced' to customers through rating systems. ${ }^{20}$ Consequently, the typical features of platform work can indicate both genuine autonomy and an extreme form of precarity, or, in the words of De Stefano, 'an extreme form of commodification of human beings'. ${ }^{21}$

2016:86 (on the challenges for the taxi industry), Konkurrensverket Working Paper 2017:1 (on challenges for competition) and Skatteverket rapport 131129 651-16/113 (on challenges for the tax system). In Denmark, see in particular Disruptionsrådet (The Disrupting Council) at https:/www.regeringen.dk/partnerskab/

${ }^{17}$ See also i.a. the 'arbeitnehmeränliche Personen' in German law and the 'para-subordinate' in Italian law, see further Waas (2017), 251-274 and Ales (2017), 351-376.

${ }^{18}$ For some examples, see Prassl and Risak (2016), 619. There are, however, examples of platforms treating their workers as employees, see, for instance, the Norwegian platforms WeClean and Foodora at www.weclean.no and www.foodora.no.

${ }^{19}$ In the judgment of 10 November 2017 in Employment Appeal Tribunal, Y. Aslam, J. Farrar and others v. Uber, Uber drivers were classified as workers. The question of employee status was not at issue.

${ }^{20} \mathrm{~A}$ crowd of workers seeking customers, combined with a high number of customers rating them, can ensure effective objective control over worker conduct, as emphasised by the Advocate General's reflections in case C-434/15 Uber Spain, EU:C:2017:364, para 52.

${ }^{21}$ De Stefano (2016), 477. 
Lastly, fragmentation on the receiving end is a central aspect of platform work. The triangular contractual structure defines platform work and represents a clear split in employer functions. The platform-worker contract sets a framework for the specific exchange of work and pay. The corporate platform structure can represent further fragmentation, as different companies may be involved in recruiting and contracting with workers, and with the day-to-day management of the platform. ${ }^{22}$

In addition, platform work also raises jurisdictional issues and questions related to the choice of law. These complexities accelerate when such issues are addressed in the contractual terms, presupposing that the workers are independent contractors. ${ }^{23}$ Such challenges are, however, not further elaborated in this article.

In sum, these aspects of platform work represent a serious threat to the effective application of labour law protection and to the contract-of-employment test as the legal instrument to ensure it. The threat needs to be addressed to guarantee effective protection for platform workers and to set the ground for fair competition.

\section{A Scandinavian perspective}

\subsection{Introduction}

It is important to address the challenge of platform work from the national-law perspective. Apart from the free movement and equality law, EU law has traditionally, for the most part, left it to national law to define the contract of employment. ${ }^{24}$ Recent jurisprudence reflects an increasing significance of EU law concepts. ${ }^{25}$ Recent legislative initiatives from the EU may strengthen this tendency. ${ }^{26}$ However, EU law does not cover all aspects of labour law, and national law may set higher protective standards. The national contract-of-employment tests are therefore still important when determining the scope of labour law protection.

The idea of what constitutes a contract of employment in different national jurisdictions has a common basis. Notions of dependency and subordination, and the idea of the primacy of the facts, are central in most European jurisdictions. Still, as the test and classification practices vary from country to country, so do the problems related to them. A perspective combining jurisdictions where common features dominate, and where the challenges related to platform work are similar, seems a fruitful point of departure.

As elaborated in this section, the contract-of-employment tests in Scandinavian countries share important common features. ${ }^{27}$ Compared to British law, the challenges related to platform work are different and less threatening to the scope of labour law protection.

\subsection{Common features of the Scandinavian tests}

The regulatory approach in Scandinavia is basically jurisprudential..$^{28}$ The contract of employment is not defined in the legislation, there are no general statutory definitions of employee/employer,

${ }^{22}$ For instance, Uber drivers contract with the Rasier (based in the Netherlands) for the right to use software, while a national company, i.a. Uber Norway, recruits drivers and handles questions regarding performance etc., see Hotvedt (2016b).

${ }^{23}$ For instance, the Uber-driver contract contains an arbitration clause and regulates the choice of law, see Hotvedt (2016b).

${ }^{24}$ As regards free movement, see i.a. case 75/63 Unger, EU:C:1964:19, and case 66/85 Lawrie-Blum, EU:C:1986:284. As regards equality law, see i.a. case C-256/01 Allonby, EU:C:2003:190. The traditional approach is reflected in case 105/84 Danmols, EU:C:1985:331, and the Transfer of Undertakings Directive (2001/23/EC) art. 2.1.d.

${ }^{25}$ See in particular case C-232/09 Danosa, EU:C:2010:674, case C-393/10 O'Brien, EU:C:2012:110, case C-229/14 Balkaya, EU:C:2015:455 and case C-216/15 Ruhrlandsklinik, EU:C:2016:883. For further discussion, see Kristiansen (2016b) and Hotvedt (2018).

${ }^{26}$ The Commission has proposed to replace the Written Statement Directive (91/533/EC) with a new directive on transparent and predictable working conditions, see $\operatorname{COM}(2017) 797$ final. The proposed directive builds on the EU law concept of worker in order to ensure a uniform implementation, and it aims at strengthened protection for workers in non-standard forms of employment, i.a. platform workers.

${ }^{27}$ Källström (2002) and Nielsen (2016), 493.

${ }^{28}$ Perulli (2011), 138-139, distinguishes between a jurisprudential and legislative approach. 
and where definitions are given, they provide limited guidance. Instead, classifying the contract of employment has traditionally been left to jurisprudence. The test is a multi-factor test, requiring a broad assessment of the realities of the parties' relations, guided by a list of indicators or criteria. The idea of coherency (a unitary concept) has been influential, providing a common basic understanding of the contract type. Yet coherency has not been fully achieved. In all three jurisdictions, there are variations regarding both statutory definitions and classification practices. Thus, although the contract of employment has common core characteristics, the classification of a given relation may depend on the field of law in question and the type of legal basis (statutory or collective agreement).

In Norway, the main legislative instruments on the individual and collective level (the Working Environment Act and the Labour Disputes Act) define the contract of employment indirectly by defining its parties. The employee ('arbeidstaker') is defined simply as any person performing service work and there is a clear assumption that the relation has a contractual basis..$^{29}$ Other statutory labour standards such as the Holiday Act are based on the same basic concept, although no explicit definition is given..$^{30}$ Broadly termed, but slightly different definitions of the employee (and employer) occur in legislation regarding tax, social security, work insurance and tort. ${ }^{31}$ Furthermore, the criteria listed to guide the assessment are slightly different in tax and social security law compared to labour law. Case law also reveals variations in the significance of factors in these areas, as the overall assessment is affected by the purpose of the relevant rule. ${ }^{32}$

Swedish labour law does not provide any statutory definition of the employment contract ('anställingsavtal') or the concept of employee ('arbetstagare'). The employee concept is explained in doctrinal work as a person who, on the basis of a contract, personally performs work for someone else and is instructed to do so by the other party (the employer) in return for remuneration. ${ }^{33}$ Despite this apparently coherent notion, classification practices in case law vary to some extent. ${ }^{34}$ The variations are related to the type of dispute, the parties involved and the purpose of the rules in question..$^{35}$

Denmark shares a tradition of refraining from detailed statutory definitions of employment contracts ('ansættelseskontrakt') and the employee concept ('lønmodtager'). A broadly termed definition was, however, introduced in the act implementing the Written Statement Directive in 1993, where employees are defined as 'persons who receive remuneration for personal services in an employment relationship' ${ }^{36}$ The preparatory works illustrate the tension between the idea of a coherent concept and varying distinction and classification practices. The definition was intended to correspond with the definition in tax legislation and provide general guidance; yet the need for an independent assessment was underlined. ${ }^{37}$ As no uniform definition has been developed in case law, classification practices will, to a certain degree, depend on the rules in question..$^{38}$

Furthermore, the contract-of-employment tests in all three countries are based on largely similar criteria. This can, at least in part, be explained by a common doctrinal basis. The nature of the contract of employment described by the 'founding father' of Norwegian labour law, Paal Berg, and some decades later, by Axel Adelcreutz, has influenced all three countries. ${ }^{39}$ Adelcreutz's approach to the employment contract as a social form of cooperation prepared the ground for the broad assessment of the circumstances in the individual case, focusing on particular criteria.

${ }^{29}$ Lov 17. juni 2005 nr. 62 om arbeidsmiljø, arbeidstid og stillingsvern mv. (arbeidsmiljøloven) § 1-8 (1) og lov 27. januar $2012 \mathrm{nr} .9$ om arbeidstvister (arbeidstvistloven) $§ 1$ (a).

${ }^{30}$ Lov 29. april $1988 \mathrm{nr} .21 \mathrm{om}$ ferie (ferieloven).

${ }^{31}$ Lov 17. juni 2005 nr. 67 om betaling og innkreving av skatte- og avgiftskrav (skattebetalingsloven) § 4-1 (1) c. Lov 28. februar $1997 \mathrm{nr} .19$ om folketrygd (folketrygdloven) § 1-8, lov 16. juni $1989 \mathrm{nr}$. 65 om yrkesskadeforsikring (yrkesskadeforsikringsloven) $\S 2$ and lov 13. juni $1969 \mathrm{nr}$. 26 om skadeserstatning (skadeserstatningsloven) $\S 2-1 \mathrm{nr} .2$ and 3.

${ }^{32}$ For further references, see Hotvedt (2016a), 146-151 and 358-365.

${ }^{33}$ Inghammar (2017), 680. The landmark case NJA 1949 s. 768 set the basis for a coherent concept.

${ }^{34}$ Inghammar (2017), 681 and AD 1981 nr. 105.

${ }^{35}$ Källström and Malmberg (2016), 29-33.

${ }^{36}$ The directive (91/544/EEC) was implemented by Ansættelsesbevisloven, consolidated by Lbkg nr. 240 af 17 March 2010.

${ }^{37}$ Kristiansen (2016a), 21-22.

${ }^{38}$ Kristiansen (2017), 133, Hasselbalch (2013), 29-32.

${ }^{39}$ Adelcreutz (1961) refers to Berg (1930), see i.a. 11. On the further influence of Adelcreutz, see Källström (2002), 84 and Källström and Malmberg (2016), 26. 
In Norwegian law, the criteria indicating a contract of employment are repeatedly cited in preparatory works and by the Supreme Court:

- the worker is obliged to stay in service to perform personal work and cannot use substitutes on his/her own account;

— the worker is obliged to submit to the employer's supervision and control of the work;

- the employer provides the work location, machines, tools, work materials or other equipment necessary to perform the work;

- the employer bears the risk for the work result;

— the worker is remunerated by some form of wage;

- the parties' relation is relatively stable and is terminable with notice;

- the worker mainly works for one employer. ${ }^{40}$

Also in Swedish law, preparatory works and government documents list the following criteria to indicate that a person is an employee if he or she:

— is personally obliged to perform the work, whether it is stated in a (written or oral) contract or could be presumed by the parties to the contract;

— has himself or herself, personally or practically personally, performed the work;

- is at the disposal (of the employer) continuously for work arising within the business of the employer;

- has a contractual relationship with the other party which is of a continuous, or of a 'more lasting', character;

- is prohibited, under the contractual arrangement or as a consequence of the conditions of work (time or capacity for other work), from undertaking similar work on behalf of someone else;

- is, for the performance of the work, subject to the employer's instruction and control in relation to how, where and when to carry out the work;

- has to use the machinery, tools or material provided for by the other party (the employer);

- is compensated for direct expenses, such as travel costs;

— is remunerated for the work effort, at least partially, by a guaranteed salary;

- is, economically and socially, in a similar position to an employee. ${ }^{41}$

As regards Danish law, Hasselbalch summarises the following main criteria:

— the degree of the employer's right to direct and control the work performed by the person in question (subordination);

- the arrangement of the financial relationship between the parties (including tax law issues and the worker's entrepreneurial risk);

- the obligation to carry out the work personally or the right to have someone else perform the tasks;

- the personal relationship between the worker and the employer, including the place of work; and

- the worker's social and occupational position, especially whether the worker is primarily considered to be comparable with an employee or a self-employed worker. ${ }^{42}$

All lists include criteria pointing to the obligations that make the contract fundamentally asymmetric and a basis of personal dependency: a continuous relation of personal work under subordination. Other criteria concern the distribution of economic risks between the parties and type of remuneration, and aim at revealing the 'real' nature of the relation: whether the exchange, in reality, is one of personal labour or a specific result that can be achieved without personal subordination. The lists also include criteria that describe the duration and/or stability of the relation, its economic importance for the worker and a 'social' assessment. These criteria target relations of actual economic dependency. In sum, the criteria therefore aim at identifying different kinds of dependency, both personal and economic, both contractual and actual.

Lastly, the norms guiding the overall assessment are similar, while not necessarily identical. The tests require a facts-oriented, dynamic, individualised and purposive assessment based on, but not restricted to, the listed criteria. The broad- and facts-based nature of the assessment is expressed by the

${ }^{40}$ Ot.prp. nr. 49 (2004-2005) s. 73 (author's translation). The list is cited by the Supreme Court in Rt. 2013 s. 354, para 38, see also Rt. 2013 s. 342 and HR-2016-1366-A.

${ }^{41}$ SOU 1993:32, 227, translation by Inghammar (2017), 686. Doctrinal work formulates the criteria somewhat differently, see Källström (2002), 85, Schmidt and Sigeman (1994) 65, Adelcreutz and Mulder (2013), 66-67 and Källström and Malmberg (2016), 26-27.

${ }^{42}$ Hasselbalch (2009), 67, translation by Kristiansen (2017), 141. See similarly Hasselbalch (2013), 31-32. 
criteria themselves. The assessment is not limited to contractual obligations, practices are relevant, and when considering the nature of contractual obligations, the focus is on the actual performance..$^{43}$ The assessment is dynamic and takes account of practice developments between the parties. ${ }^{44} \mathrm{An}$ individual approach is reflected in the relevance of criteria indicating economic dependency and the assessment should (in principle) include all the (relevant) circumstances in each specific case. ${ }^{45}$

The purposive approach is significant. In all three countries, variations in definitions and classification practices are closely related to the purpose of the relevant legal framework. ${ }^{46}$ The purposive element is considered stronger in Denmark and Norway compared to Sweden. ${ }^{47}$ Recent developments in Norway indicate a strengthened purposive element. ${ }^{48}$ The Supreme Court explicitly regards their 'methodological approach' a purposive one, and the Court has repeatedly stated that the purpose of the labour law legislation is to provide protection for those who need it. ${ }^{49}$ This approach has justified extensive applications of the contract-of-employment test in recent jurisprudence. ${ }^{50}$

\subsection{Scandinavian tests compared to British law}

A brief comparison with British law will shed further light on the distinctive features of the contract-of-employment tests in Scandinavian law. The comparison will reveal that the Scandinavian tests are better equipped to deal with the challenges of platform work. It will also serve to identify a core common challenge for the Scandinavian tests when dealing with platform work.

Already at the point of departure, the British common-law approach to identifying a contract of employment is distinctively different from the Scandinavian approach. British law allows for a spectrum of tests and criteria to be considered. In modern case law, however, the mutuality-of-obligation test dominates compared to other relevant tests (the control-, integration- and economic-reality tests), and is, according to Prassl, 'by far the most prominent in practice today'. ${ }^{51}$ The mutuality-of-obligation test represents a strong focus on the exchange of promises regarding the employer's obligation to provide work and the employee's obligation to accept work. In case law, the obligation to provide and undertake work is considered 'the irreducible minimum of mutuality of obligation necessary to create a contract of service' ${ }^{52}$ As described above, the Scandinavian tests reflect a broader and more facts-oriented approach.

Several other differences add to the impression of a British test with a stronger emphasis on formal contractual arrangements and bilateral exchange and - consequently - a narrower understanding of the contract of employment.

One difference concerns the ability to reveal a 'sham'. The formal classification of the contract is clearly relevant in British law and may be regarded as 'strong evidence' of the real relationship. ${ }^{53} \mathrm{In}$ contrast, the Norwegian Supreme Court regards the formal status of the contract (as a contract for service) as a matter of no significance in the contract-of-employment test due to the protective purpose of the rules in question. ${ }^{54}$ The other Scandinavian traditions consider this as a factor of limited importance. The facts revealing the 'real' contractual realities are generally more significant, otherwise it would undermine the protective purpose. ${ }^{55}$

\footnotetext{
${ }^{43}$ Källström and Malmberg (2016), 28, Kristansen (2014), 21 and Hotvedt (2016a), 365-385.

${ }^{44}$ Källström and Malmberg (2016), 28 and Hotvedt (2016a), 375.

${ }^{45}$ This is elaborated in section 4.1 .

${ }^{46}$ Källström and Malmberg (2016), 28-29, Adelcreutz and Mulder (2013), 59, Hasselbalch (2013), 30-31, Kristiansen (2016a), 22 and Hotvedt (2016a), 146-148.

${ }^{47}$ Källström (2002), 79 and Nielsen (2002), 152-175.

${ }^{48}$ Hotvedt (2018), 59.

${ }^{49}$ Rt. 2015 s. 475, para 65, Rt. 2013 s. 354, para 39, and HR-2016-1366-A, para 59.

${ }^{50}$ In Rt. 2010 s. 93, the purposive approach led to employee status in the context of work injury insurance for a man who worked for a company while also being the only shareholder, CEO and chairman of the board. In Rt. $2015 \mathrm{~s} .475$, the purposive approach led to consider a partner in a law firm as an employee in tort law, making the firm liable for the partner's negligence.

${ }^{51}$ Prassl (2015), 30 and Deakin and Morris (2009), 137-143.

${ }^{52}$ Carmichael v. National Power PLC 18 [2000] IRLR 43.

${ }^{53}$ Deakin and Morris (2009), 127-128.

${ }^{54}$ Rt. 2013 s. 354 , para 37.

${ }^{55}$ Inghammar (2017), 688, Adelcreutz and Mulder (2013), 59 and Hasselbalch (2013), 34.
} 
The next related difference is the approach to sham contractual terms. As observed by Deakin and Morris, British case law gives recent examples of an 'extremely strict view [where] there must be a finding that, at the time of the contract, both parties intended [the term] to misrepresent their true contractual relationship' ${ }^{56}$ This subjective and bilateral approach to a sham may be somewhat modified by more flexible interpretations. ${ }^{57}$ In comparison, the Scandinavian approach is fundamentally objective, focusing on whether the formal arrangement is reflected in the practical realities or not. ${ }^{58}$

There are also distinct differences in the framework of contractual law. In British contract law, mutuality - reciprocal promises and consideration - is necessary to establish a contractual bond. The focus on the exchange between two parties underpins the idea of a bilateral employment relationship and a unitary concept of the employer. ${ }^{59}$ Furthermore, there is a high threshold for an implied contractual bond. Conduct more consistent with an intention to contract than an intention not to contract is insufficient. A contract can only be implied when a necessity test is met:

...no such contract should be implied on the facts of any given case unless it is necessary to do so; necessary, that is to say, to give business reality to a transaction and to create enforceable obligations between parties who are dealing with one another in circumstances in which one would expect that business reality and those enforceable obligations to exist. ${ }^{60}$

Scandinavian contract law provides a more flexible framework. Contractual obligations can be based on the justified expectations ('berettigede forventninger') of one party. ${ }^{61}$ A contractual bond is thus based on a broader assessment, considering not just the parties' expressed will and conduct, but also taking power asymmetries and societal values (protecting the weaker party) into account. The threshold for implying a contractual bond - and contractual terms - is therefore to some extent adaptable to the type of contract in question, potentially responding to the protective purpose related to a contract of employment. Not surprisingly, behaviour implying a contract of employment - such as performing and receiving work - can be sufficient to establish a contract of employment. ${ }^{62}$

These observations may explain the distinctively different approaches to the types of challenges related to platform work in Scandinavian law compared to British law.

First, the Scandinavian tests are better equipped than the British ones are to face the challenge of shams. The closer scrutiny of formal contract classifications and expressed terms should make it easier to question platform workers' formal status as independent contractors, and the contractual terms offered to them. Second, casual work arrangements, work with both dependant and autonomous features, are treated differently. Third, the tests reflect different approaches to employer-side fragmentation, in particular, the triangular contractual structure of agency work. The Scandinavian tests are clearly more inclusive than the British tests when faced with both causal work arrangements and agency work. In sum, the contractual framework of employment contracts seems less of a 'straightjacket' for the scope of labour law in Scandinavian law compared to British law. This will be explained in more detail.

As regards casual work arrangements, the mutuality of obligation leaves British law generally excluding. The mutuality-of-obligation test rests on the exchange of mutual promises of future performance - the employer's obligation to provide work and the employee's obligation to accept work - as an inherent part of an employment contact, as a second level of obligation, adding to the first level of the exchange of work for remuneration. ${ }^{63}$ Obligational mutuality to maintain the employment relationship could serve as a basis for certain rights and obligations within the employment contract (as implied terms

\footnotetext{
${ }^{56}$ Deakin and Morris (2009), 129, with reference to Consistent Group Ltd. v Kalwak, [2008] IRLR 508, para 51.

${ }^{57}$ See in particular the Protectacoat Firthglow Ltd v Szilagyim [2009] IRLR 365, cf. Deakin and Morris (2009), 129.

${ }^{58}$ Inghammar (2017), 678, Källström (2002), 85, Hasselbalch (2013), 34, Kristiansen (2017), 143 and Hotvedt (2016a), 365-385. This, however, does not exclude a strict approach to attempts to circumvent employer responsibility, see i.a. Källström and Malmberg (2016), 31, who especially underline the importance as regards the circumvention of collective agreements.

${ }^{59}$ Prassl (2015), 18-19.

${ }^{60}$ This citation from The Aramis [1989] 1 Ll.L.R 213 is repeated in case law concerning employment, see i.a. James $v$ London Borough of Greenwich [2008] EWCA Civ 34, examined below. See further Prassl (2015), 88-90.

${ }^{61}$ Hotvedt (2016a), 299-301, with further references to Norwegian, Swedish and Danish law.

${ }^{62}$ Källström and Malmberg (2016), 27 and Hotvedt (2016a), 313-316 and 319-321.

${ }^{63}$ Deakin and Morris (2009), 138.
} 
or as a normative basis for statutory requirements). In British law, however, the mutuality-of-obligation test assumes the second level of obligation to be a precondition for a contract of employment, and, hence, for employment protection. ${ }^{64}$ Without a mutual obligation to provide and accept work, casual work arrangements are not likely to be considered contracts of employment. So-called zero-hour contracts, for instance, are therefore likely to be excluded from employment protection in British law.

Mutuality of obligation also has an excluding effect on agency work. The agency-worker relation is typically not a contract of employment in British law, as such reciprocal obligations are usually lacking. ${ }^{65}$ The control test has also failed, as case law has focused on the agency-worker relation separately and has not taken the triangular structure into account. ${ }^{66}$ Furthermore, an (implied) contract of employment in the worker-end user relation is hindered by the framework of contractual law, more precisely by applying the 'necessity test' ${ }^{67}$ As the worker's service to the end user and the user's payment via the agency were explicable by the triangular contractual structure (genuine express contracts between the worker and agency, and agency and end user), an implied contract was not justified as necessary. Paradoxically, the court took account of the triangular contract structure in this regard.

In sum, British law seems generally dismissive of the idea of a contract of employment in the casual and triangular arrangement of platform work. ${ }^{68}$ The Scandinavian approach, on the other hand, is more promising.

Agency workers are generally considered to have employment contracts in Scandinavian law. Criminally sanctioned restrictions on the use of agency workers were liberalised in all three countries in the 1990s. Although agency work challenges the notion of a bilateral employment relationship, it is broadly accepted as a (specific) type of employment contract. ${ }^{69}$ The problem of the triangular structure is therefore mainly an issue of the allocation of employer responsibilities, and not a scope issue. In Denmark, however, one particular scope issue remains. The specific employment-protection statute for white-collar workers does not apply to agency workers. ${ }^{70}$ The allocation issue is, at least in part, solved by statutory intervention. The agency is generally considered the employer as the employee's contractual counterparty, while specific employer duties are assigned to the end user. ${ }^{71}$ There are also distinct differences as regards the nature and degree of the end-user's employer responsibility in Scandinavian countries.

\begin{abstract}
Norwegian law assigns the broadest responsibility, as the duties of the end user relate not just to health and safety and discrimination, but also to working time, pay and employment protection. The end user is under joint liability for the agency's obligation to provide pay. ${ }^{72}$ Of particular importance is the 'bridge' between restrictions on temporary work and the end-user's employment-protection responsibility: Restrictions on the use of temporary employment contracts also apply to the use of agency workers, and if the restrictions are not respected, the worker is entitled to claim a regular, open-ended employment contract with the end user. ${ }^{73}$
\end{abstract}

Notwithstanding such differences, the acceptance of an employment contract in the agency-worker relation reflects a comprehensive approach to triangular contractual structures. The relation between the worker and end user legitimately affects the classification of the agency-worker relation. The triangular contractual structure of platform work is therefore not an insurmountable obstacle to the contract-of-employment test in Scandinavian law. Norwegian case law gives recent examples of such a comprehensive

\footnotetext{
${ }^{64} \mathrm{Ibid}$.

${ }^{65}$ Prassl (2015), 87-88 and Deakin and Morris (2009), 138.

${ }^{66}$ Bunce v. Postworth Limited t/a Skyblue [2005] IRLR 557, see further Prassl (2015), 88.

${ }^{67}$ James $v$ London Borough of Greenwich [2008] EWCA Civ 34.

${ }^{68}$ This can explain why the Uber lawsuit, Y. Aslam, J. Farrar and others $v$. Uber, concerned the status as a 'worker' not as an 'employee'.

${ }^{69}$ On Swedish law, see Selberg (2017), 62, on Danish law, see U.1999.1870S and Kristiansen (2016a), 23, on Norwegian law, see Hotvedt (2016a), 144 and LF-1999-216 (Norway), where the existence of a contract of employment was undisputed and the case concerned the allocation of employer responsibilities.

${ }^{70}$ Funktionærloven, Lbkg nr. 81 af 3.2.2009, cf. U.1997.1495H.

${ }^{71}$ Lag 2012:854 om uthyrning av arbetstagare $1 \S, 11 \S$ (Sweden), Lov nr. 595 af 12.6.2013 om vikarers retsstilling ved udsendelse af et vikarbureau (Denmark), WEA $\S$ 14-12 and further, § 2-2, § 13-2 (Norway).

${ }^{72}$ WEA $\S 14-12 \mathrm{c}$.

${ }^{73}$ WEA § 14-12 (1), cf. § 14-9 (1) litra a-e. The most liberal basis for temporary work, § 14-9 (1) f, does not apply to agency work.
} 
approach to other triangular contractual structures. ${ }^{74}$ When applying the test to the platform-worker relation, a comprehensive approach would, by analogy, allow for the subordination and control of the workercustomer relation to affect the assessment of the platform-worker relation when facilitated by the platform.

As regards casual work arrangements, the Scandinavian approach is clearly less excluding than the British approach. Due to the broad and facts-oriented nature of the test, a mutual obligation to provide and accept work in the future is not a necessary prerequisite. However, an ambiguous approach to workers' freedom to accept or decline work and specific tasks is present. On the one hand, an obligation to stay in service is a criterion of central importance, and stability and continuity are relevant. On the other hand, the purposive approach (considering social factors) favours including casual formal work arrangements. This ambiguity is illustrated by Norwegian case law. The Supreme Court regarded a 'loose connection' as a strong argument against an employment contract, as it left the worker without the duty of performing personal work in the regular sense. ${ }^{75}$ A more recent case, however, reflects a more nuanced view. In Rt. 2013 s. 354, the Supreme Court recognised the need for protection arising from a casual work arrangement as relevant in the contract-of-employment test. Still, the Court did not question the traditional criteria - neither the 'duty to stay in service' nor the stability of the relation.

The case concerned a worker providing support services for a family with a disabled child. The services were granted by the local government, and the worker entered into subsequent short-term contracts, formally framed as contracts of service. The contract defined the support-service hours but left it to the worker (and the family) to decide on the time and place for work, and how the work was to be performed. After a close assessment of the traditional criteria, the Court concluded the worker had a contract of employment with the local government. When considering the control criteria, the Court assessed how, in reality, the worker had little influence over how the work was performed.$^{76}$ Interestingly, the Court also emphasised that a short-term contract without a right to renewal and future work weakened the worker's bargaining position, and continued:

Therefore, there is a relationship of dependency and subordination, which is a fundamental feature of contracts of employment. ${ }^{77}$

\begin{abstract}
A similar argument surfaced when considering the stability of the relation. Four subsequent contracts of two months' duration provided sufficient stability to weigh in favor of a contract of employment, and the right to terminate the contract at any time was not a determining counter-argument. In passing, the Court mentioned that this 'might as well' illustrate the worker's precarious position. ${ }^{78}$
\end{abstract}

Swedish law reveals a parallel ambiguity. On the one hand, work defined as a predetermined limited task and the right to decline work are considered strong arguments against a contract of employment. ${ }^{79}$ On the other hand, the 'social criteria' focus on dependency due to precarity and the value of the freedom to decline work for an economically dependent worker have been seriously questioned.$^{80}$ In Denmark, the ambiguity is sharply illustrated by the partial employee status of agency workers. The lack of a duty to perform work at the request of the employer is the reason why agency workers are not granted statutory employment protection. ${ }^{81}$

Fragmentation due to the complexity of corporate platform structures is clearly challenging in the Scandinavian context. Relatively speaking, this challenge is still less threatening, as it mainly concerns the allocation of responsibility (effectiveness) and not the existence of an employment contract (scope). Furthermore, the response in Scandinavian law seems divergent and a common approach is thus less suitable. ${ }^{82}$ This challenge is therefore not pursued in the present article. That being said, due to a more

\footnotetext{
${ }^{74}$ Rt. 2013 s. 354 , Rt. 2013 s. 342 and HR-2016-1366-A.

${ }^{75}$ Rt. 1984 s. $1044,1048-1049$.

${ }^{76}$ Rt. 2013 s. 354, paras 45-47.

${ }^{77}$ Rt. 2013 s. 354, para 48. Author's translation, emphasis added.

${ }^{78}$ Rt. 2013 s. 354, para 55. Author's translation.

${ }^{79}$ Ds 2002:56, in particular 117, 132.

${ }^{80}$ Ibid.

${ }^{81}$ U.1997.1495H, see further Kristiansen (2017), 138.

${ }^{82}$ See Hotvedt (2016a) for further references. Källström and Malmberg (2013), 31, especially underline the importance as regards the circumvention of collective agreements.
} 
flexible contractual-law framework and the purposive element, there is considerable potential to challenge the corporate veil in the platform context.

In Norwegian law, for instance, contractual obscurity as to who is the contractual employer is solved by a purpose-oriented and openly functional approach. Even though the contract's formal identification of the party is the starting point, case law also considers whether this corresponds (to a reasonable degree) with the allocation of employer functions. ${ }^{83}$ Furthermore, there is a distinct doctrine on joint employer responsibility, merging corporate- and contractual-law arguments with the protective purpose of labour law. The doctrine represents a 'second step' in allocating employer duties. If responsibility for the contractual employer (the 'first step') does not correlate reasonably with the actual influence on the employment relationship, the question of responsibility for other entities is considered more closely. The prevailing line of argument in case law to form the basis for joint responsibility is a combination of a close integration of the relevant entities, by ownership or otherwise, a contractual basis for certain employer functions and the actual exercise of managerial powers. ${ }^{84}$

In conclusion, the ambiguity of freedom in platform work can be regarded as a core common challenge for the Scandinavian contract-of-employment test.

\subsection{A required renewal}

As explained above, the Scandinavian contract-of-employment tests reflect an ambiguous approach to the freedom of platform workers. The current criteria do not guide the distinction and leave the fundamental question unresolved: How can the test separate cases where worker freedom indicates autonomy from cases where it is a hallmark of dependency and precarity? To provide a fair and predictable scope for employment law, the test should guide this distinction in a clear and operational manner. ${ }^{85}$ When it does not, the test does not really address the need for protection related to platform work.

Consequently, a renewal is not just needed, it is required. A requirement to adapt the criteria to the changed realities of work stems from the test's legal nature. Three arguments support this claim and explain why a renewal within the current jurisprudential approach, without statutory efforts, is preferable.

First, the test's jurisprudential basis makes it flexible and adaptable. ${ }^{86}$ This approach has been maintained despite significant changes in the labour market and after careful consideration of alternative approaches such as detailed definitions and new intermediary categories. ${ }^{87}$ The prevailing argument is that a flexible test is the best way to adapt to changed realities and new forms of work. More detailed statutory definitions would leave the test more static and make labour law more vulnerable to circumvention. New intermediary categories could increase uncertainty and complexity without solving the pressing issues. ${ }^{88}$ As stated in the preparatory works of the WEA, the test should evolve to reflect changed realities:

Even more importantly, there should be room for developing the concept [of employee], corresponding to new ways of organising work and new work relations. This development can and should happen in jurisprudence. The Committee finds that the criteria and overall assessment applied by the courts, to a sufficient degree, respond to the need for flexibility and predictability. The Committee, however, expects future court decisions to reflect further developments in the labour market. ${ }^{89}$

Secondly, the criteria are not legally binding as such. The criteria are empirically-based indicators of a contract of employment, derived from its usual characteristics. In Norway and Sweden, the criteria were

\footnotetext{
${ }^{83}$ See Hotvedt (2016a), 426-440 for further references.

${ }^{84}$ See in particular Rt. 2012 s. 983 , Rt. 1990 s. 1126 and Rt. 1989 s. 231 . See also Hotvedt (2016a), 441-463.

${ }^{85}$ ILO Recommendation 198 (2006) concerning the employment relationship reflects a responsibility to review national law or practice to ensure a clear and effective scope for labour law protection.

${ }^{86}$ This is explicitly stated regarding Norwegian law in Ot.prp. nr. 49 (2004-2005), 73 and regarding Swedish law in Adelcreutz (1961), 217.

${ }^{87}$ Preparatory works to WEA 2005 discussed and rejected an intermediary category in Norwegian law, see NOU 2004:5, 153-157, 163. See a similar assessment as regards Swedish law in Ds 2002:56, 128, 133-134.

${ }^{88}$ See i.a. De Stefano (2016), 494-499 and Prassl and Risak (2016), 622-624.

${ }^{89}$ NOU 2004:5, 163. Author's translation, emphasis added.
} 
listed in preparatory works decades ago to describe the typical employment relationship at that time..$^{90}$ The lists are not non-exhaustive, as reflected in the varying formulations in legal doctrine and in jurisprudence emphasising other factors. The criteria are simply tools to help apply the underlying norms to the practical realities, based on what has been the usual characteristics of a contract of employment. It follows that changed modes of work - like platform work - give reasons to consider supplementing with new criteria.

Thirdly - and perhaps most importantly - the purposive approach requires a continuous review of whether the traditional criteria provide guidance that helps fulfil the purpose of the legal framework. ${ }^{91}$ If taken seriously, the purposive approach implies that the criteria must change if they no longer reflect the purpose.

The purposive approach, however, also provides guidance on how to renew the criteria. Renewed criteria can be derived from a broad purposive approach, by considering both the needs of the individual and the platforms' market role, and by including Scandinavian labour-market values.

\section{A broad purposive approach}

\subsection{The individual perspective: Providing labour law protection for those who need it}

Thus far, the purposive approach has mainly focused on the individual need for protection. The Norwegian Supreme Court regards the purpose of labour law as providing protection for those who need $i t$, and the main purpose is similarly phrased in the other Scandinavian countries. ${ }^{92}$

This individual perspective is expressed by criteria pointing at individual characteristics, in particular, criteria concerning economic dependency and social factors. In principle, the overall assessment include all relevant circumstances in the individual case. ${ }^{93}$ Case law shows that individual factors can be the determining argument. In a series of cases on hairdressers' employment status, the Swedish Labour Court found the duration of the relation and even the workers' age to be important factors. ${ }^{94}$

An individualised approach has been suitable to address and provide fair results in individual borderline cases, in particular, work formally framed as separate independent contracts, that in reality amount to stable, full-time work for one employing entity. Yet, such an approach is less suited to addressing the challenges of platform work, where the need for protection is related to the business model and to the lack of stability it represents. Empirical studies in Scandinavia indicate that platform work is often performed occasionally. ${ }^{95}$ The work is, however, not necessarily marginal and ancillary to other sources of income. How much work each worker undertakes, how long the relation lasts and how much the worker depends on this income, can vary considerably between workers on the same platform. ${ }^{96}$ To provide a clear and predictable scope for employment law, the distinction needs to be made between platform models rather than between individual workers. An individual economic-dependency perspective is thus not well suited as a decisive factor.

Another aspect of the individual perspective, however, is highly relevant to platform work. As platform workers generally have the freedom to choose their tasks, hours and places of work, control of

\footnotetext{
${ }^{90}$ In Norway, a list was first introduced in preparatory works to Lov 14. november $1947 \mathrm{nr} .3$ om ferie (The Holiday Act 1947). The Swedish multifactor test was introduced in the preparatory works to Lag (1976:580) om medbestämmande i arbetslivet (Co-determination Act 1975), see Inghammar (2017), 685-686.

${ }^{91}$ This is an important task for both jurisprudence and legal doctrine, see i.a. Ds 2002:56, 128, 131.

${ }^{92}$ Källström and Malmberg (2016), 29, emphasise the individual's need for protection ('skyddsbehovet') as the starting point of the assessment. Hasselbalch (2013), 70, explains the protective purpose as partly preventing the parties from disturbing the statutory level of social protection and partly preventing the employer from abusing the power asymmetries vis-à-vis the employee.

${ }^{93}$ Inghammar (2017), 687, refers to NJA 1949 s. 768 as the 'break-through' case of a social concept of the employee in Swedish law, see further Adelcreutz and Mulder (2013), 59-60.

${ }^{94}$ AD $1978 \mathrm{nr}$. 7, AD $1979 \mathrm{nr} .12$ and AD $1982 \mathrm{nr}$. 134. See further Inghammar (2017), 687. Rt. 1968 s. 725 is an example from Norwegian jurisprudence, see further Hotvedt (2016a), 386-390.

${ }^{95}$ Dølvik and Jesnes (2017), 22-26.

${ }^{96}$ For evidence in a Norwegian context, see Jesnes et al. (2016), 31.
} 
their work performance seems a particularly important indicator of subordination. As explained above in regard to agency work, the Scandinavian contract-of-employment tests allow for a comprehensive approach to supervision and control in triangular contractual structures. The perspective of the individual worker and the focus on the need for protection justifies this approach.

Consequently, when considering subordination in the platform-worker relation, customer control should be part of the picture. Norwegian case law already gives several examples of a parallel assessment in other triangular work arrangements. ${ }^{97}$ The fact that work performance was supervised and controlled by the end user and not by the alleged employer was not decisive in the eyes of the Supreme Court, as the worker would otherwise be left in a void, without employment protection. ${ }^{98}$ Thus, 'outsourcing' supervision and control to another party should not result in the worker falling outside the scope of labour law protection. Platforms usually have rating systems, facilitating work performance being reflected in the customer's rating of workers. If platforms use ratings to sanction worker behaviour, it is arguably an indirect form of supervision and control. Therefore, the more the platform lets the ratings affect the worker's opportunities to work via the platform, the stronger this indicates subordination.

To summarise: The individual perspective is a basis for a comprehensive assessment of the supervision and control of work performance in platform work. The assessment should include both supervision and control by the platform (direct control) and customer supervision and control when facilitated and actively used by the platform (indirect control). If the platform monitors worker performance and lets customer ratings affect the worker's position, it is a clear indication of subordinated work.

\subsection{The market perspective: The market role of platforms}

The purpose of the regulatory framework is not solely to protect the individual worker. As indicated in the introduction, the contract of employment has a key function in labour-market regulation. A broad purposive approach could - and should - include the platform's market role to protect this function.

A certain market perspective is already included in the Scandinavian contract-of-employment tests. Several criteria concern the distribution of economic risks by focusing on which party bears the investment costs (by providing tools and materials, and a work location) and the risk for the work result etc. However, these criteria may be misleading when applied to platform work. In a traditional twoparty relation, the focus is on the distribution of risks between the worker and the alleged employer. The triangular platform model, however, allows platforms to profit directly from the services provided by workers without investing in equipment etc., and without accepting the risk for the work result vis-à-vis the worker. The criteria are thus less fit to guide the distinction between different platform models. They also leave the test open for evasion, as platforms can effectively avoid indicators of a contract of employment via unilaterally-set conditions. The criteria need to reflect the triangular platform model and take the varying market role of platforms into account.

Platforms generally provide an intermediary service of digitally connecting workers and customers. Typically, platforms see themselves as mere intermediaries, providing only such information society services. Yet the degree of involvement in the underlying service varies across different platform models. Some platforms are deeply involved in defining, organising and controlling the underlying service while others are not. As the degree of involvement relates to variations between platform models, not between individual workers, it could be an operational parameter in the contract-of-employment test. Important indicators of such involvement are platform influence or control on the type, quality and price of the service, and on other contractual terms in the worker-customer relation.

Such criteria seem highly relevant in a labour law context, as it sheds light on worker freedom in the triangular model of platform work: The more the platform is involved in providing the underlying service to the customer, the more the worker acts on behalf of the platform, and not as an independent operator vis-à-vis the customer. Platform involvement in defining the nature of the service, price and

\footnotetext{
${ }^{97}$ Rt. 2013 s. 354, Rt. 2013 s. 342 and HR-2016-1366-A.

${ }^{98}$ See in particular Rt. 2013 s. 354, para 49.
} 
other terms also adds to the worker's economic dependency vis-à-vis the platform as it limits the worker's possibilities for bearing risks and attaining profits. The criteria are well in line with the concept of worker in EU law. The Commission regards platform involvement as indicative of subordination, and distinguishes between situations where the platform determines the type of work, remuneration and other working conditions from situations where the platform merely processes pay from the end user. ${ }^{99}$

Similar criteria are relevant in market law, when classifying platform services to determine the relevant set of market rules. ${ }^{100}$ The main instrument in EU secondary legislation, the Services Directive, gives precedence to provisions governing specific aspects of access to, or the exercise of, a service activity in specific sectors if they conflict with the Directive, i.a. the E-Commerce Directive, with specific provisions concerning information society services. ${ }^{101}$ Conversely, services in the field of transport are exempt from the Directive and subject to specific provisions. ${ }^{102}$

The Commission considers the level of control or influence over the underlying service to be of significant importance for market law classification and has highlighted three key criteria: whether the platform sets the final price, whether the platform sets other terms and conditions in the worker-customer relation and has ownership of key assets used to provide the service. ${ }^{103}$ The Court of Justice of the European Union (CJEU) has recently, in two cases concerning the Uber-platform, ruled that provisions for information society services do not apply if the service is 'more than an intermediation service' by being 'inherently linked' to the underlying service, making the intermediary service an 'integral part of an overall service whose main component' is the underlying one (in these cases, transport). ${ }^{104}$ When finding an inherent link the CJEU noted that those drivers would not be led to provide transport services to those customers without the use of the platform. ${ }^{105}$ The CJEU also emphasised that 'Uber exercises decisive influence over the conditions under which that service is provided by those drivers', and pointed to involvement in the price and quality of the service. ${ }^{106}$

Furthermore, platform involvement in the underlying service affects platform liability. The ECommerce Directive limits liability for providers of information society services for content they do not control. ${ }^{107}$ Even if the Directive applies, the liability exemptions may not apply if the platform has an active role in determining the content of the underlying service. ${ }^{108}$

An autonomous labour law with a distinctive normative base and independent concepts has been, and still is, of vital importance to justify labour standards and labour law institutions. ${ }^{109}$ The contract-ofemployment test should thus not depend on market-law classifications. ${ }^{110}$ Autonomy does, however, not imply insulation. ${ }^{111}$ It is recognised that labour law classifications influence market law classifications. ${ }^{112}$ A specific opposing influence is not necessarily detrimental. Rather, including market considerations that shed light on important aspects of worker freedom can help fulfil the purpose of labour law.

\footnotetext{
${ }^{99} \operatorname{COM}(2016) 356$ final, 13.

${ }^{100}$ Platforms are generally service providers under EU law as most platforms charge a fee for the contracts they mediate, and even if it is free, they can make money from publicity or the secondary use of the users' data, see Hatzpopoulos and Roma (2017), 95.

${ }^{101}$ The Services Directive (2006/123/EC) art. 3(1) gives precedence to i.a. the E-commerce Directive (2000/31/EC), which builds on the definition of 'information society services' in Directive 98/34/EC.

${ }^{102}$ The Services Directive art. 2(2) d. The distinction between transport and other services is also significant in the EEA agreement. Transport is not regulated by the general provisions of freedom of services (EEA art. $37 \mathrm{ff}$ ) but by specific provisions (EEA art. $47 \mathrm{ff}$, cf. art 38).

${ }^{103} \operatorname{COM}(2016) 365$ final, 6.

${ }^{104}$ Case C-434/15 Uber Spain, EU:C:2017:981, para 37, 40 (emphasis added), and case C-320/16 Uber France, EU:C:2018:221, para. 21, 22.

${ }^{105}$ Case C-434/15 Uber Spain, para 39, and case C-320/16 Uber France, para. 21.

${ }^{106}$ Ibid.

${ }^{107}$ The E-Commerce Directive arts. 12, 13 and 14.

${ }^{108}$ Hatzopoulos and Roma (2017), 103-105.

${ }^{109}$ Different aspects of autonomy are explored in Bogg et al. (2015).

${ }^{110}$ Section 3.3 illustrates how notions of contractual law, in particular, the mutuality of obligation and the 'necessity test' limit the scope of labour law protection in British law.

${ }^{111}$ Other fields of law such as human rights law and discrimination law have undisputedly served to develop (and expand) the protective rationale of labour law. Recent literature also provides fruitful perspectives drawing on commercial and EU market law, see i.a. Bogg et al. (2015), parts III and IV.

${ }^{112} \operatorname{COM}(2016) 356$ final, 6.
} 
The Advocate General's opinion in case C-434/15 Uber Spain reflects how the classification issues in market law and labour law are interrelated but not interdependent. First, he assumes that platform involvement in the underlying service indicates a contract of employment, since it can serve the same purpose of managing workers as traditional means of control do:

While this control is not exercised in the context of a traditional employer-employee relationship, one should not be fooled by appearances. Indirect control such as that exercised by Uber, based on financial incentives and decentralised passenger-led ratings, with a scale effect, makes it possible to manage in a way that is just as - if not more - effective than management based on formal orders given by an employer to his employees and direct control over the carrying out of such orders. (Para 52)

Then, he explicitly refrained from concluding that market-law classification should determine labour law classification:

The above finding does not, however, mean that Uber's drivers must necessarily be regarded as its employees. The company may very well provide its services through independent traders who act on its behalf as subcontractors. The controversy surrounding the status of drivers with respect to Uber, which has already resulted in court judgments in some Member States, is wholly unrelated to the legal questions before the Court in this case. (Para 54)

The last quote may reflect a remaining challenge: Even if platform involvement in the underlying service is accepted as relevant guiding criteria, these criteria must be aligned with other criteria indicating autonomy for platform workers. One might face the argument that workers' freedom to choose tasks and hours are the determining characteristics even when the platform is deeply involved.

In other words, there is a missing link. A legal argument is needed to bring the platform-involvement criteria to the centre of the test and to make them more important than the (ambiguous) freedom of platform workers. The last section suggests that Scandinavian labour-market values can serve as this missing link.

\subsection{The Scandinavian labour-market values}

The Scandinavian labour-market values give normative support to shifting the platform-involvement criteria in the underlying service into the centre of the test when dealing with platform work.

The Scandinavian labour-market model is, in comparative terms, characterised by strong labourmarket actors enjoying a high degree of collective autonomy with a high level of social protection for the individual. The interplay between state and labour-market actors is close and coordinated: ${ }^{113}$ The legislator leaves key labour law issues to collective bargaining and the labour-market actors have a strong influence on legislative processes. Thus, the labour-market actors execute important regulatory functions regarding labour law protection. Statutory labour law and regulation by collective agreements interact on both a practical and normative level. This close cooperation also extends to broader issues of welfare protection and economic policy. Assigning regulatory (and political) power to the labour-market actors is an institutional arrangement of the Scandinavian labour market, making the cooperation between the state and labour-market actors an essential part of the societal model. ${ }^{114}$

There is, however, not a unitary Scandinavian (or Nordic) model. There are significant differences, i.a. regarding the degree of regulatory powers conferred to the labour-market actors. In Denmark, their regulatory powers are the broadest, as collective agreements are the primary regulatory instrument, and statutory protection is scant and scattered. The state and the dominating labour-market actors share an understanding of collective agreements as preferable to statutory protection, and legislative efforts are usually only activated when the labour-market actors agree on the need and content of such protection. ${ }^{115}$ In Sweden, statutory protection is more developed, and provides i.a. employment protection and co-determination standards with a general scope. Still, as many labour law standards can be derogated

\footnotetext{
${ }^{113}$ Evju (2010), Bruun et al. (1990).

${ }^{114}$ Evju (2010), see in particular 3, 5-6.

${ }^{115}$ Kristiansen (2014), 20-21.
} 
by collective agreements and important issues such as the minimum wage are not regulated, collective agreements are considered the main regulatory instrument. ${ }^{116}$ The statutory approach is more significant in Norway. However, Norwegian labour law legislation leaves room and leverage for collective agreements. There is no statutory minimum wage, and co-determination standards and regulations on working time allow certain derogations via collective agreement. ${ }^{117}$

Despite such differences, the Scandinavian societal model presupposes and underpins the key functions of the contract of employment: It is the basis for the labour-market actors' institutional role. The regulatory framework, both statutory and collectively bargained, relies heavily on the contract of employment as a tool to regulate the labour market, distribute welfare rights and obligations, and provide economic stability. Hence, the contract of employment is a key instrument to ensure that labourmarket involvement triggers responsibility for labour-market risks. To fulfil these functions, the contract of employment must be the dominating form of organised work both on the societal and company level.

Ensuring that labour-market involvement is followed by responsibilities for welfare protection and protecting the contract of employment as the main form of organised work are therefore fundamental Scandinavian labour-market values. They are legal values as they are presupposed by, and inherent in, the legal framework. The purposive approach to the Scandinavian contract-of-employment test provides a legal basis for their relevance when applying the test.

In Norway, these values are explicitly and authoritatively expressed. Government documents and preparatory works clearly state that labour-market regulation aims at ensuring the contract of employment (in its regular form, a direct, two-party, open-ended contract) as the dominating form of organised work both on the societal and company level. ${ }^{118}$ This has served to justify both purposive interpretations of casual terms of employment and statutory interventions to ensure effective employment protection in triangular and casual working arrangements such as agency work and on-call work. ${ }^{119}$

These values would be threatened if the platform-worker relation is not recognised as a contract of employment where the platform is actively engaged in the labour market via its deep involvement in the underlying service.

In short, Scandinavian labour-market values imply that platform involvement in the underlying service is a key parameter when applying the contract-of-employment test, and is more significant than the (ambiguous) freedom of platform workers to choose their tasks and hours.

\section{Conclusion: Renewed criteria ... and?}

In conclusion, a broad purposive approach combining the individual and the market perspectives and including Scandinavian labour-market values can clarify the distinction between platform workers and platform contractors by renewing the criteria guiding the contract-of-employment test.

This article suggests that the test should focus on the platform control of work performance (directly and indirectly, via the use of customer ratings) and platform involvement in the underlying service (influence or control of the type and quality of service, price and other contractual terms vis-à-vis the customer).

These criteria indicate both personal subordination and economic dependency. They enhance consistency with EU law and market law without depending on them. The criteria seem to provide a clearer distinction regarding the diversity of platform models, while not getting lost in the diversity of workers. Last, but not least, they protect the key functions of the contract of employment in the labour market.

Implementing renewed criteria is primarily a task for the judiciary, yet a renewed test is not sufficient. To provide effective labour law protection, the test must be applied and enforced in practice. Bringing a case to trial is a risky, costly and timely operation. Contractual clauses on arbitration, the choice of law and confidentiality can further discourage platform workers. Relying on union support

\footnotetext{
${ }^{116}$ Westregård (2017).

${ }^{117}$ WEA chs. 8 and 10.

${ }^{118}$ See i.a. Innst.O. nr. 2 (1994-95), 29, Ot.prp. nr. 49 (2004-2005), 208, Prop. 74 L (2011-2012), 13-14.

${ }^{119}$ From jurisprudence, see i.a. Rt. 2005 s. 826 and Rt. 2013 s. 1730. For a recent statutory initiative addressing causal work arrangements, see Prop. 73 L (2017-2018).
} 
seems risky, as unions face particular problems organising platform workers. Thus, it may be time to consider, in cooperation with the social partners, a separate institution for the cheap and speedy legal determination of employment status: An Employment Status Board. In Scandinavia, there are already several boards etc. which are competent in deciding specific labour law-related issues, so why not on the key issue of employment status? $?^{120}$

Such an institution could be well suited to addressing the grey area, bringing the platform models out of the shadows and ensuring a predictable legal framework for the future.

\section{Bibliography}

Adelcreutz, A. (1961), Arbetstagarbegreppet (Stockholm: P.A. Norstedt \& Söners Förlag).

Adelcreutz, A. and B.J. Mulder (2013), Svensk arbetsrätt (Stockholm: Norstedts Juridik, 14. ed).

Ales, E. (2017), “The concept of 'employee': The position in Italy", in B. Waas and G.H. van Voss (eds), Restatement of Labour Law in Europe. Vol 1. The Concept of Employee (Oxford: Hart Publishing), 351-375.

Berg, P. (1930), Arbeidsrett (Oslo: Olaf Norlis forlag).

Bogg, A., C. Costello, Acl Davies and J. Prassl (eds) (2015), The Autonomy of Labour Law (Oxford: Hart Publishing).

Bruun, N., B. Flodgren, M. Halvorsen, H. Hydén and R. Nielsen (1990), Den nordiska modellen (Malmö: Liber Förlag).'

Casale, G. (2011), “The employment relationship: A general introduction”, in G. Casale (ed), The Employment Relationship: A Comparative Overview (Oxford/Geneva: ILO and Hart Publishing), 1-33.

Creighton, B. and S. Mccrystal (2016), "Who is a 'worker' in international law?", in Comparative Labor Law and Policy Journal, 37, 691-725.

DeAKIN, S. and G. Morris (2009), Labour Law (Oxford: Hart Publishing, 5. ed.).

De Stefano, V. (2016), "The rise of the 'just-in-time workforce': In-demand work, crowdwork and labor protection in the 'gig-economy"', Comparative Labor Law \& Policy Journal, 37, 471-503.

DøLVIK, J.E. And K. JeSNes (2017), "Nordic labour markets and the sharing economy: Report form a pilot project", TemaNord 2017:508.

Evıu, S. (2010), "Kollektive autonomi, den 'nordiske modell' og dens fremtid", in Arbeidsrett, 7, 1-29.

Freedland, M. and N. Kountouris (2011), The Legal Construction of Personal Work Relations (Oxford: Oxford University Press).

Hasselbalch, O. (2009), Den Danske Arbejdsret, Bind 1 (København: Jurist- og Økonomforbundets Forlag).

Hasselbalch, O. (2013), Arbejdsret (København: Jurist- og Økonomforbundets Forlag, 11. ed.).

Hatzopoulos, V. and S. Roma (2017), "Caring for sharing? The collaborative economy under EU Law", Common Market Law Review, 81, 81-128.

HJeLmenG, E. (2016), "The concept of an 'undertaking': On the borderline between competition law and labour law", in B.J. Mulder, M.J. Hotvedt, M. Nesvik and T.L. Sundet (eds), Sui Generis: Festskrift til Stein Evju (Oslo: Universitetsforlaget), 316-326.

HotveDt, M.J. (2016a), Arbeidsgiverbegrepet (Oslo: Gyldendal Juridisk).

Hotvedt, M.J. (2016b), “Arbeidsgiveransvar i formidlingsøkonomien? Tilfellet Uber”, Lov og Rett, 55, 484-503.

Hотvedt, M.J. (2018), “Arbeidstaker - quo vadis?”, Tidsskrift for rettsvitenskap, 131, 42-103.

Inghammar, A. (2017), "The concept of 'employee': The position in Sweden”, in B. Waas and G.H. van Voss (eds), Restatement of Labour Law in Europe. Vol 1. The Concept of Employee (Oxford: Hart Publishing), 677-696.

${ }^{120}$ One Norwegian example is Tvisteløsningsnemnda, which decides on disputes concerning working time, parental leave, the extension of part time work etc., see WEA § 17-2. Another is Diskrimineringsnemnda, which decides on complaints regarding discrimination, see Lov 16. juni 2017 nr. 50 om Likestillings- og diskrimineringsombudet og Diskrimineringsnemnda (diskrimineringsombudsloven). 
Jesnes, K., B.s. Øistad, K. Alsos and T. Nesheim (2016), “Aktører og arbeid i delingsøkonomien”, Fafonotat 2016:23.

KRISTIANSEN, J. (2016a), Grundlæggende arbejdsret (København: Jurist- og Økonomforbundets Forlag, 4. ed.).

KRistiansen, J. (2016b), “På vej mod et europæisk arbejdstagerbegrep?”, B.J. Mulder, M.J. Hotvedt, M. Nesvik and T.L. Sundet (eds), Sui Generis: Festskrift til Stein Evju (Oslo: Universitetsforlaget), 389-398.

Kristiansen, J. (2017), “The concept of 'employee': The position in Denmark”, in B. Waas and G.H. van Voss (eds), Restatement of Labour Law in Europe. Vol 1. The Concept of Employee (Oxford: Hart Publishing), 133-148.

KällströM, K. (2002), "Employment agreements and contract work in the Nordic countries”, Scandinavian Studies of Law, 43, 77-86.

KäLlström, K. and J. MaLmberg (2016). Anställingsförhållandet (Uppsala: Iustus Förlag, 4. ed).

NieLsen, R. (2002), "Arbejdstagerbegrebet i et arbeidsmarked under forandring", in Arbejdsretsligt Tidsskrift, 152-175.

Nielsen, R. (2016), Dansk arbejdsret (København: Jurist- og Økonomforbundets Forlag, 3. ed).

Perulli, A. (2011), "Subordinate, autonomous and economically dependent work: A comparative analysis of selected European countries", in G. Casale (ed.), The Employment Relationship: A Comparative Overview (Oxford/Geneva: ILO and Hart Publishing), 138-187.

Prassl, J. (2015), The Concept of the Employer (Oxford: Oxford University Press).

Prassl, J. and M. Risak (2016), "Uber, Taskrabbit, and Co.: Platforms as employers? Rethinking the legal analysis of crowdwork", Comparative Labor Law \& Policy Journal, 37, 619-651.

Roverud, L.H., T.к. KuøLVIK, T. Nesheim and K. Jesnes (2017), "Mellomledd i oppdragsmarkedet", Søkelys på arbeidslivet, 34, 199-215.

Schmidt, F. and T. Sigeman (1994), Löntagarrätt (Stockholm: Juristförlaget, rev. ed.).

SelBerg, N. (2017), Arbetsgivarbegreppet och arbetsrättsligt ansvar i komplexa arbetsorganisationer (Lund: Lund University).

Sundararajan, A. (2016), The Sharing Economy: The End of Employment and the Rise of Crowd-based Capitalism (Cambridge, MA: The MIT Press).

Supiot, A. (2001), Beyond Employment: Changes in Work and the Future of Labour Law in Europe (Oxford: Oxford University Press).

Veneziani, B. (1986), "The evolution of the contract of employment", in B. Hepple (ed), The Making of Labour Law in Europe (London/New York: Mansell Publishing), 31-72.

WAAs, B. (2017), “The concept of 'employee': The position in Germany”, in B. Waas and G.H. van Voss (eds), Restatement of Labour Law in Europe. Vol 1. The Concept of Employee (Oxford: Hart Publishing), 251-274.

Westreg̊̊RD, A. (2017), “Collaborative economy - a new challenge for the social partners", in K. Ahlberg, P.H. Olsson and J. Malmberg (eds), Niklas Bruun i Sverige (Uppsala: Iustus Förlag), 427-438. 